\title{
Chapter 12 \\ The Spatial Mobility of Corporate Knowledge: Expatriation, Global Talent, and the World City
}

\author{
Jonathan V. Beaverstock
}

Expatriation, and other forms of labor mobility that cross international borders within and between firms is a crucial organizational strategy for the spatial mobility of knowledge in the world economy. At the organizational level, firms deploy their knowledge-rich, managerial, and expert human capital to circulate both tacit and explicit (codified) knowledge between subsidiaries, clients, and suppliers; to develop the organization; and to service existing and new clients outside of the home country. Expatriation is a process that stretches tacit knowledge across time and space (Beaverstock, 2004; Faulconbridge, 2008) because of the importance of "being (there)" (Gertler, 2003) to manage, engage in the production system, and service clients in co-location. Far from being on the wane in these times of advanced information technology and communication, expatriation is a strategic mechanism for a firm to deliver knowledge, skills, expertise, and experience to a particular point in space and time (e.g., an office, subsidiary, or gas extraction field) (Beaverstock, 2004; Edström \& Galbraith, 1977; Millar \& Salt, 2009; PricewaterhouseCoopers, 2010a; Scullion \& Collings, 2006).

Expatriation is a vital global organizational strategy for knowledge-intensive professional services in sectors such as accountancy, consulting, and law in which the delivery of knowledge, tailor-made solutions, and value is embodied in the employee, especially if the reputation and credentials of the firm rests on the success of the professional employee-client relationship (Beaverstock, 2004; Faulconbridge, 2008; Jones, 2008). Beyond the firm, expatriation feeds into the competitiveness of cities and regions acting as a conduit to replenish knowledge, skills, and know-how in local labor markets. Indeed, many world city boosterists and commentators suggest that attracting and retaining global talent is a significant factor of production in the success of a world city in the network society (Beaverstock, 2010; Castells, 1996; Florida, 2002; Wigley, 2008).

J.V. Beaverstock $(\bowtie)$

School of Economics, Finance and Management, University of Bristol, Bristol, UK

e-mail: jonathan.beaverstock@ bristol.ac.uk 
The contribution of this chapter is to advance the theoretical and empirical understanding of contemporary forms of expatriation as an organizational strategy for the spatial mobility of knowledge and as a global process that enhances the competiveness of the world city in an age of highly integrated, global information, communication, and telecommunication (ICT) systems. Accordingly, the rest of this chapter is divided into seven parts. Following this introduction, parts two, three, and four focus on explaining the significant concepts that underpin the strategy of expatriation as a physical medium of knowledge creation, transfer, and exchange within organizations and between different spatial contexts. In part two, I examine the structural organization of firms and their mechanisms for creating, sharing, and exchanging knowledge within the multilocation organization, drawing primarily on the work of transnational management theorists, Bartlett and Ghoshal (1998). Part three is a review of human resource perspectives that explain the organizational strategy of expatriation and their role in the firm's global knowledge management system. I look in part four at the agency of place, the world city, in concentrating and reproducing knowledge management within the network society (Castells, 1996) and enhancing the expatriate's spatial knowledge networks and career paths (Beaverstock, 2005, 2010). In parts five and six I introduce case studies of expatriation within global accountancy firms and discuss the agency of foreign workers in the competitiveness of London's financial district (Beaverstock, 2007a, 2010; Beaverstock \& Hall, 2012). I conclude in part seven and argue that expatriation will continue to be a significant form of knowledge development, transfer, and exchange within organizations, and an essential driver for spatial economic development and competiveness.

\section{The Firm, International Business Strategy, and Knowledge Management}

Increasingly, the resource of knowledge (e.g., the traits of high-value-added professionalism, expertise, skills, and intelligence, whether in the established professions, research and development $[\mathrm{R} \& \mathrm{D}]$, medicine, science or engineering), is often a sticky, tacit competence embodied in human capital (Gertler, 2003; Lowendahl, 1997). The management of that knowledge, on a global scale, has become a key strategy (and challenge) for firms (Schuler, Jackson, \& Tarique, 2011; Scullion, Collings, \& Caligiuri, 2010; Whelan, Collings, \& Donnelian, 2010). It is now readily acknowledged that transnational firms organize their assets, labor, interests, and client and supplier relationships in dynamic and complex networks that span world regions in many different commodity and value chains (Dicken, 2011). Simultaneously, firms are transnational communities, a collective of complex interrelationships and amalgamations of employees of all nationalities, status, and skillsets, with the transnational corporation (TNC) being a

,...thick web of communication possibilities vertically and horizontally...[where]...

$[\mathrm{m}]$ anagers' careers would be varied and involve movement across different subsidiaries as 
well as into head office. Senior management would reflect a wider group of nationalities and experiences than in the multinational enterprise. Learning would be dispersed, often disorganized but usually multi-directional in terms of its effect. (Morgan, 2001, p. 120)

However, in order to get a more refined and structural explanation of how knowledge is created and shared between a firm's international subsidiaries, at a conceptual level, one can draw on the writings of two eminent management theorists, Christopher Bartlett and Sumantra Ghoshal, in their widely acclaimed Managing Across Borders: The Transnational Solution (1998). Bartlett and Ghoshal (1998) provide a conceptual model to analyze how corporate knowledge, both tacit and codified, is developed and disseminated within the international multilocational firm which can provide a framework to account for the strategy of firms that engage in global staffing and expatriation.

Bartlett and Ghoshal (1998) suggest that a core competence of the multilocational firm is the "development and diffusion of knowledge" (p. 75) within the organization in order to efficiently manage assets, capabilities, and operations across borders (Table 12.1). According to the authors' four-pronged organizational typology of the structure of the firm managing across borders-multinational, global, international, and transnational - each of them manages its organizational characteristics differently. If one focuses on the "development and diffusion of knowledge," it is possible to observe a linear progression in the sharing of knowledge, from a multinational structure, in which knowledge is "developed and retained in each unit." to a transnational structure, in which knowledge is "developed jointly and shared worldwide" (Bartlett \& Ghoshal, 1998, p. 75; Table 12.1). As I have noted elsewhere (Beaverstock, 2004), the key attribute of knowledge development

Table 12.1 Organizational characteristics of the transnational firm

\begin{tabular}{lllll}
\hline $\begin{array}{l}\text { Organizational } \\
\text { characteristics }\end{array}$ & Multinational & Global & International & Transnational \\
\hline $\begin{array}{l}\text { Configuration of } \\
\text { assets and } \\
\text { capabilities }\end{array}$ & $\begin{array}{l}\text { Decentralized } \\
\text { and nationally } \\
\text { self-sufficient }\end{array}$ & $\begin{array}{l}\text { Centralized and } \\
\text { globally scaled }\end{array}$ & $\begin{array}{l}\text { Sources of } \\
\text { core } \\
\text { competences } \\
\text { centralized, }\end{array}$ & $\begin{array}{l}\text { Dispersed, } \\
\text { interdependent, and } \\
\text { specialized }\end{array}$ \\
& $\begin{array}{l}\text { others } \\
\text { decentralized }\end{array}$ & \\
$\begin{array}{l}\text { Role of overseas } \\
\text { operations }\end{array}$ & $\begin{array}{l}\text { Sensing and } \\
\text { exploiting local } \\
\text { opportunities } \\
\text { and strategies }\end{array}$ & $\begin{array}{l}\text { Implementing } \\
\text { parent company } \\
\text { competencies }\end{array}$ & $\begin{array}{l}\text { Adapting and } \\
\text { leveraging } \\
\text { parent } \\
\text { company }\end{array}$ & $\begin{array}{l}\text { Differentiated } \\
\text { contributions by } \\
\text { national units to }\end{array}$ \\
$\begin{array}{l}\text { Development } \\
\text { and diffusion of } \\
\text { knowledge }\end{array}$ & $\begin{array}{l}\text { Knowledge } \\
\text { developed and } \\
\text { retained within } \\
\text { each unit }\end{array}$ & $\begin{array}{l}\text { Knowledge } \\
\text { developed and } \\
\text { retained at the } \\
\text { core }\end{array}$ & $\begin{array}{l}\text { Knowledge } \\
\text { developed at } \\
\text { the center and } \\
\text { transferred to }\end{array}$ & $\begin{array}{l}\text { Knowledge } \\
\text { developed jointly } \\
\text { and shared }\end{array}$ \\
\end{tabular}

Adapted from Bartlett \& Ghoshal (1998, p. 5) 
and diffusion in transnational firms is that knowledge is circulated both vertically (up and down between headquarters and subsidiaries) and horizontally (laterally between subsidiaries) among all units of the firm. Transnational firms are integrated networks spanning cross-border activities, sustained by communication and mobility between different subsidiaries and the head office (Beaverstock, 2007a, p. 411)

In a similar vein to Bartlett and Ghoshal (1998), Nohria and Ghoshal (1997, p. 4) define the firm as a "differentiated network" reflecting the network structure of the organization made up of a multitude of linkages, chains, and relationships: (a) the local linkages within each national subsidiary; (b) the linkages between headquarters and the subsidiaries; and (c) the linkages between headquarters and the subsidiaries themselves", with the latter, unlike (b), also including linkages between the subsidiaries.

There is now sufficient evidence to suggest that firms manage their knowledge development and diffusion through complex systems of knowledge management that draw upon a combination of physical and virtual dissemination and exchange, regardless of whether they exhibit Bartlett and Ghoshal's (1998) international or transnational organizational characteristics (Faulconbridge, 2008; Mellahi, Frynas, $\&$ Finlay, 2005). Firms are relational entities with sophisticated knowledge management systems to develop, share, and exchange explicit and codified knowledge through electronic transmission and virtual proximity using efficient and confidential transmission systems and ICT, including videoconferencing software and, latterly, intra-firm social networking systems. But if one considers the development, diffusion, and exchange of tacit knowledge, which is often very sticky and embodied in the experience, competences, expertise, skills, and learning capacities of an individual, the most efficient—and possibly cost-effective-mechanism to transfer those embodied attributes cross-border from subsidiary A to subsidiary B is to move the individual physically through, for example, business travel (Faulconbridge, Beaverstock, Derudder, \& Witlox, 2009) or an international assignment (Brewster \& Scullion, 1997; Collings, McDonnell, Gunnigle, \& Lavelle, 2010; Scullion \& Collings, 2006).

Moreover, the advent of the transnational form of the contemporary firm has created the conditions for the development of a globally functioning, international division of highly skilled executive, established professional and managerial, and high-value scientific labor (in fields such as medicine, technology, R\&D, and engineering). This global labor market is inherently reproduced through local labor markets, but importantly also through the burgeoning number of international assignments and other types of cross-border hypermobile work (for example, those involved in regular business travel, short-term rotations, and fly-in and fly-out timespecific contract work) present in many industrial sectors of the world economy, such as aerospace and mineral extraction (Millar \& Salt, 2009), professional services (Beaverstock, 2004; Faulconbridge, 2008; Jones, 2010), executive education (Hall, 2009), banking and financial services (Beaverstock \& Hall, 2012), high technology (Harvey, 2008), and IT and R\&D (Mahroum, 2000; Saxenian, 2007). In order to examine further the significance of inter- and intra-firm international assignments as a mechanism for knowledge management and exchange within and 
between firms, it is important to draw on the International Human Resource Management (IHRM) discipline and to discuss the organizational strategy of expatriation and global staffing systems.

\section{Expatriation, Global Talent, and Knowledge Exchange}

Irrespective of significant advancements in global ICT, TNCs use international assignments as a fundamental internationalization strategy to transfer and exchange knowledge, expertise, and learning to and among foreign subsidiaries or other forms of global investment. These international assignments are synonymous with the organizational label expatriation (Brewster, 1991; Tung, 1988). In the discipline of business studies an entirely new branch of management science with the apt name of International Human Resource Management (IHRM) developed in the late 1960s to focus on this segment of a firm's internal labor market. The crux of this new field is the organizational strategies posited to explain why TNCs use expatriates rather that locally recruited staff in their foreign subsidiaries, whether these are mineral/ energy extraction sites in the BRICS (Brazil, Russia, India, China, and South Africa) economies, manufacturing plants in Southeast Asia, or offices in world cities.

The TNC strategy to deploy expatriates in lieu of local, or home country nationals, is at the center of debates in contemporary IHRM (Black, Gregerson, Mendenhall, \& Stroh, 1999; Tung, 1988). Almost 50 years ago, Edström and Galbraith's (1977) seminal research on international assignments set the benchmark for clarifying why TNCs transfer staff between their subsidiaries as a way to strategically utilize their human resource capital. Edström and Galbraith (1977) recognized that the TNC adopted international assignments as an integral strategy for managing its professional and managerial employees and scientific and expert staff within the firm's portfolio of foreign investments and, therefore, in the confines of its international internal labor market. They suggested that TNCs specifically used international assignments for three main strategic purposes:

1. as a direct mechanism to fill positions and vacancies in foreign locations facing a lack of locally recruitable, qualified staff

2. as part of their internal global management development program to enhance the experience, skills, and competences of junior and mid-rank managers and professionals-irrespective of the supply of locally qualified managers in the host location; and

3. as a way to develop the global organization in regard to corporate strategy, command and control systems, and the sharing of best practice, learning, and knowledge.

Edström and Galbraith's (1977) study of the rationale for the international transfer of managers within TNCs to fill positions and to develop managers as well as the firm still resonates strongly with contemporary analyses of expatriation (Collings et al., 2010) and, more latterly, scholarship on firms' global staffing regimes and global talent management (Scullion \& Collings, 2006). 
In Collings and Scullion's (2006) review of global staffing and expatriation, they synthesized the findings of other contemporary IHRM scholars in order to interrogate further Edström and Galbraith's (1977) writings on the foundations of international assignments within TNCs. For example, drawing on Sparrow, Brewster, and Harris's (2004) research on globalizing human resource management, they note that the TNCs' organizational strategy for sending staff on an international assignment is sixfold: for career development; to establish an international cadre of managers; to fill local vacancies resulting from a lack of qualified home-country nationals; to transfer expertise; to manage and control foreign assets; and to control global strategy and policy. Furthermore, Collings and Scullion (2006) disaggregate the purpose of expatriation into two conceptual frames (after Evans, Pucik, \& Barsoux, 2002). First, they are demand-driven assignments, which resonates with the organizational requirement to fill vacancies, manage new investments, or solve problems in situ because of a dearth of locally qualified home country nationals. Second, they are learning-driven assignments intended to drive individual career development and serve as a mechanism to transfer, share, and exchange knowledge between the expatriate and home country nationals. Most empirical studies of the social characteristics of corporate-transferee expatriates from the United States, Europe, and Japan derived from research by scholars of IHRM indicate these workers are predominately male, with men holding an average of $85 \%$ of such positions across all industrial sectors, as much as $95 \%$ in construction and engineering, and a relatively low $70 \%$ in not-for-profit and charity employment (Shortland, 2009). ${ }^{1}$

From the early 2000s, the business discourse surrounding TNCs and international assignments has shifted away from expatriation, to understanding the global staffing of organizations as talent management or talent mobility (Tarique \& Schuler, 2009). Long before Florida (2002) revisited the subject of talent, the root of its meaning and representation was brought onto the social sciences stage by the pioneers of creativity and space (e.g., Meusburger, Funke \& Wunder, 2009), but it is in the realm of business and management studies that globally nomadic, professional, managerial, or very expert scientific workers are referred to as global talent. For example, in 2000 PricewaterhouseCoopers (2000a, 2000b) reported on expatriates in the discourse of traditional international assignments, focusing on their business rationale, global compensation packages, and predicted futures. A decade on, PricewaterhouseCoopers (2010a) published a new framework on international assignments focused on Talent mobility 2020, which is not out of sync with other global consulting firms (for example, Deloitte's [2012] report on The Global Talent Challenge or The Corporation of London's [2011] study of Access to Global Talent). The longevity of expatriation as an organizational strategy currently stems from its usefulness in the global management of intellectual capital in high value occupations and skills, reflecting the intensifying shift away from multinational firm struc-

\footnotetext{
${ }^{1}$ Research on expatriates in subjects such as their household formation, employment, identity, gender, ethnicity, sexuality, community formation, and mobility also has gathered significant interest across the social sciences disciplines, including human geography, sociology, and, of course, migration studies (e.g., Fechter \& Walsh, 2012; Smith \& Favell, 2006).
} 
tures (i.e., the dissemination of knowledge primarily from the corporate headquarters to subsidiaries) to the transnational mode, or the sharing and exchange of knowledge and staffing between all units of the firm (described by Bartlett \& Ghoshal [1998] as the transnational form of the firm). As PricewaterhouseCoopers (2010a) notes:

Assignments in the past were typically categorised by organisations as being either shortterm or long-term. Today we see many more varied requirements from businesses and assignees and alignment with the organisation's talent management objectives. Along with short-term and long-term assignments, we have frequent travellers, commuters, intraregional, and virtual secondments to customers and supplier sites, as well as various assignee and talent types, such as executive, skill set and project-based, developmental, and employee initiated, all creating a need for robust global assignment policy framework. (p. 16)

PricewaterhouseCoopers (2010a, p. 6) predicts that the average number of international assignments worldwide at 900 companies listed in its sample database will have grown $50 \%$ from 2009 levels by 2020 to approximately 400,000. Significantly, PricewaterhouseCoopers suggests that much of this growth in global mobility will be generated by and in the emerging markets, as more skilled employees from these countries enter the global talent pool. Therefore, expatriation as an organizational strategy is an increasingly important facet of the TNC's portfolio of global talent mobility (Beaverstock, 2010; Faulconbridge et al., 2009; Millar \& Salt, 2009). The role of international assignments reflect on the one hand the requirements of the firm to be competitive in a highly globalized world, both in terms of business systems and location, and on the other, the expectations of talent to have high-valueadded, mobile careers enhancing promotion prospects, personal remuneration, and a cosmopolitan sense of well-being (Beaverstock, 2011; Beaverstock \& Hall, 2012). But it must be acknowledged that more assignees will necessitate "more business travel, more virtual tools, and especially more quick, short-term, and commuter assignments" (PricewaterhouseCoopers, 2010a, p. 4).

\section{World Cities, Expatriation, and the Spatial Mobility of Knowledge}

Invariably, in the manufacturing and service sectors of the world economy, the organizational structure and location of the firm provides an overwhelmingly urban working and living experience for the expatriate. Expatriates are city dwellers throughout the globe. But there is a growing body of evidence to suggest their agency, practice, and performativity are crucial processes accounting for the geoeconomic sustainability, competiveness, and relationalities of world cities (Beaverstock, 1994, 2011; Ewers, 2007; Friedmann, 1986; Sassen, 2001a, 2006). Indeed, many commentators have discussed the role of highly skilled international migrants (Beaverstock, 1994, 2005, 2007b), "transnational elites" (Friedmann \& Wolff, 1982), the "new international professionals" (Sassen, 2001b), and "dominant 
managerial elites" (Castells, 1996) in the making of world cities and their complex intercity relations and networks. In many ways, organizational processes of expatriation, talent management, and global staffing are nourishing the knowledge bases of world cities, providing a continuous throughflow of talent into these places that secures them high rankings in the many commercial, highly influential global urban hierarchies, such as Z/Yen's Global Financial Center Index 11 (2012), Mastercard's (2008) Worldwide Centers of Commerce Index, or the Mercer Group's (2011) Quality of Living Worldwide City rankings.

The expatriate, like home country elites, is pulled into world cities and their organizational networks through intra- or inter-company transfers initiated by the firm or potential employer, or through other migratory paths, such as those of free-movers, or European Union (EU) citizens able to migrate at will throughout the EU single market (Favell, 2008). The structural position of world cities in the new international division of labor (Cohen, 1981; Hymer, 1972; Friedmann, 1986) ensures that their spatial economies have unprecedented "global reach" and "command and control" (Sassen, 2001a) derived from high concentrations of corporate headquarters; significant agglomeration economies (clusters) in international finance, professional services, media, and education; health service, medicine, biotechnology, R\&D, and creative and cultural industries; cutting-edge information technology and communication; and state-of-the-art infrastructure (Cook, Pandit, Beaverstock, Taylor, \& Pain, 2007; Olds, 2007; Sassen, 2006). The firms in these high-value world city economies, whether TNCs or small and medium-sized enterprises in manufacturing or services, create the unprecedented conditions driving demand for highly skilled labor that are articulated in a globally functioning, spatial division of labor (Beaverstock \& Boardwell, 2000). Moreover, during the last 40 years or so, the growth of the producer service "complex" in world cities (Sassen, 2006), particularly in those of the Global North-London, New York, Chicago, Boston, Los Angeles, Paris, Frankfurt, Brussels, Madrid, and Amsterdam-have shaped the circumstances for brisk labor market demand in sectors such as advertising, banking, financial services, professional services (accounting, consulting, legal, real estate), and information technology (City of London, 2011). But the growth of the producer complex has not been limited to European and North American cities. For example, in Singapore approximately one million jobs were created in the service sector between 1991 and 2008, of which a third (some 320 thousand) were in financial and professional services, such as accounting, legal, and real estate (Ministry of Manpower, 2009). Similar structural changes are occurring in Moscow (Kolossov, Vendina, \& O'Loughlin, 2002), Hong Kong (Meyer, 2000), Shanghai (Lai, 2009), and Mumbai (Patel, 2007).

World city economies are important structural agents in the spatial mobility of knowledge. Their internal structure, global reach, and economic authority, which are manifested in complex intra- and inter-city networks, are perpetuated through the high-value, knowledge-rich labor force attracted to work and live in these places (Beaverstock, 2005). Essentially, world cities are the global melting pots for highly talented workers of all nationalities, both internal and international, who fill vacancies and labor market demand in the high-value-added, knowledge-intensive complexes of the city (whether in finance, professional services, creative industries, the 
media, or R\&D). The bottom line is that expatriation and other forms of mobility such as business travel are key organizational strategies to deliver skills and expertise and to learn at the point of demand, often through the medium of face-to-face interaction. "Face-time" remains a very efficient and valued mechanism to exchange tacit knowledge over time and space, in working environments that depend on direct interaction with clients to ensure quality of service and leadership as well as to deliver tailor-made solutions, problem solving, and complex management systems (Beaverstock, 2007a, 2007b; Faulconbridge, 2008; Jones, 2008).

Finally, it is also important to acknowledge that world cities have significant agency in enhancing an expatriate's career aspirations, wealth creation, and living experience (Beaverstock, 2005). Spatial career paths facilitate the accumulation and exchange of knowledge and learning within and between different employers and world city postings and living experiences. Expatriate career paths are a conduit in which knowledge is created and consumed in world city networks, particularly in an expatriate's everyday life experiences and transnational spaces (work, home, social spaces, etc.). The everyday, world-city life-worlds of expatriates supplying knowledge-intensive skills and competencies to the workplace and in "transnational social spaces" (Smith, 1999, p. 120) through "ephemeral networks and practices" (Beaverstock, 2011, p. 711) reproduce specific epistemic communities, whose life courses significantly enhance careers and the accumulation of financial, social, and cultural capital.

\section{Global Staffing and Expatriation in Professional Service Firms}

In the international service economy, the World Trade Organization acknowledges that people can deliver services to clients across borders through physical movement. This is an integral part of the General Agreement on Trade in Services (defined as GATS Mode 4) (Organization for Economic Cooperation and Development [OECD], 2003). In professional services, which encompass knowledge-intensive, often tailor-made and highly idiosyncratic services built on reputation and established credentials, the liberalization of trade in "natural persons" (GATS Mode 4) is essential for the firm to circulate knowledge and expertise across borders, embodied in the tacit professionalism and expertise of the archetypal "professions" like architects, accountants, or lawyers (Greenwood \& Lachman, 1996; Morris \& Empson, 1998; Lowendal, Revang, \& Fosstenlokken, 2001). The key asset of a service firm (PSF) is the knowledge capacity of its labor force of both managers and professionals, with capital accumulated, clients courted and serviced, and revenues and profits ultimately accrued through the performance of this workforce and its successful interaction with the client. Morris and Empson (1998) suggest that a PSF is "an organization that trades mainly on the knowledge of its human capital, that is, its employees and the producer-owners, to develop and deliver intangible solutions to client problems" (p. 610). Thus, in PSFs, one of the most efficient mechanisms to 
deliver knowledge, including the tacit form embodied and stuck to established professionals, is through the physical movement of such professionals from the firm to the client or within the global structure of the firm (Lowendahl, 1997). PSFs supply tailor-made knowledge and expertise to their clients and suppliers and maintain internal organizational control through co-location using personal interaction, expatriation, and hypermobility (Beaverstock, 2007a, 2007b; Faulconbridge, 2008; Faulconbridge, Beaverstock, Taylor, \& Nativel, 2011; Jones, 2008; Nachum, 1999).

Global accounting firms continue to use international assignments and other forms of corporate mobility to deliver knowledge and expertise between their international offices and firm-client relations. Over the last decade or so, global accounting has been dominated by the "Big Four"-PricewaterhouseCoopers (PwC), Deloitte, Ernst \& Young, and KPMG International-with respect to the ranking of fee income and the size of professional employment (Table 12.2). In 2010, combined, each of the Big Four employed almost half a million professional staff (partners and lawyers) in an average of 149 countries. Global accounting firms require a wholly-owned presence in each market to be able to deliver their service in colocation with the client (Dunning, 1993; Hanlon, 1994; Greenwood, Rose, Brown, Cooper, \& Hinings, 1999). Accordingly, these firms provide their major servicesaudit and assurance, corporate finance, consultancy, and insolvency (theCityUK, 2012) - through direct, on-site contact with the client, supported by an infrastructure of specialist financial products, IT software, and legal closure (certificated qualifications and membership of chartered institutes). Partners and qualified staff with relevant specializations liaise on a constant basis with clients and co-suppliers

Table 12.2 Top ten International Accountancy Networks, 2011 (Ranked by annual total income in $\$ \mathrm{~m})$

\begin{tabular}{|c|c|c|c|c|c|c|}
\hline $\begin{array}{l}\text { International network } \\
\text { organization }\end{array}$ & Headquarters & $\begin{array}{l}\text { Annual } \\
\text { Income } \\
(\$ \mathrm{~m})\end{array}$ & Countries & $\begin{array}{l}\text { Member } \\
\text { firms }\end{array}$ & Partners & $\begin{array}{l}\text { Professional } \\
\text { staff }\end{array}$ \\
\hline 1. Deloitte & New York & 26,578 & 150 & 53 & 9538 & 129,219 \\
\hline $\begin{array}{l}\text { 2. Pricewaterhouse } \\
\text { Coopers }\end{array}$ & London & 26,569 & 154 & & 8625 & 122,967 \\
\hline 3. Ernst \& Young & London & 21,255 & 142 & & 8602 & 103,393 \\
\hline 4. KPMG & Amsterdam & 20,630 & 150 & & 7921 & 105,147 \\
\hline 5. BDO & Brussels & 5284 & 119 & 96 & 4111 & 34,811 \\
\hline 6. RSM International & London & 3878 & 83 & 92 & 3113 & 23,490 \\
\hline $\begin{array}{l}\text { 7. Grant Thornton } \\
\text { International }\end{array}$ & London & 3673 & 100 & 96 & 2511 & 30,000 \\
\hline $\begin{array}{l}\text { 8. Baker Tilley } \\
\text { International }\end{array}$ & London & 3070 & 120 & 150 & 2600 & 25,000 \\
\hline $\begin{array}{l}\text { 9. Crowe Horwath } \\
\text { International }\end{array}$ & New York & 2779 & 108 & 150 & 3519 & 19,537 \\
\hline 10. PKF International & London & 2449 & 125 & 168 & 2198 & 15,292 \\
\hline
\end{tabular}

Source: compiled from Accountancy Age (2011) (www.accountancyage.com) Note. $\$ \mathrm{~m}=$ millions of dollars 
(e.g., law firms) to acquire new business, execute contracts, and deliver tailor-made services, with this work occurring in project teams with other professional services when called for by a particular business project.

The prevalence of global staffing regimes, international assignments, or other forms of mobility in the Big Four accounting firms and other smaller global firms is a normalized organizational strategy for knowledge exchange, transfer, and learning within the firm-client relationship (Beaverstock, 2007a; Hanlon, 1999). All of the Big Four have global mobility programs to fill vacancies that cannot be staffed with available local home country labor; to support management development programs for all career structures and grades within the firm; and to enhance the corporate culture of the global firm or partnership structure (Table 12.3).

PricewaterhouseCooper's (2010b) strategic approach to global mobility and leadership aptly summarizes the organizational role of international assignments in the global firms:

Moving our talent people to different locations around the world to match client and business needs is key to enabling us to offer the right expertise at the right time. An experience abroad develops the global business skills and international experience of our people...We continue to invest heavily in our global mobility programme. In FY [fiscal year] 2010, we added another 1,600 new participants to our secondment programme, up from 1,400 in FY 2009. (p. 52)

Deloitte's (2010) Annual Review champions its commitment to global mobility for its professional staff, emphasizing that mobility is all about, "moving the right people with the right skills to the right places at the right time to meet the needs of the business, clients, talent and marketplace-is a competitive imperative...Mobility opens minds, and can open opportunities" (p. 7). Beyond the Big Four, 2010 data from the U.K. accountancy professional bodies indicates that of the 424,003 qualified members, $28 \%$ were resident outside of the United Kingdom (119,720), an increase of $43 \%(36,339)$ from 2002, when 83,381 members were residing outside of the United Kingdom (theCityUK, 2012).

At the organizational level, global professional services firms are very much akin to Bartlett and Ghoshal's (1998) global and transnational organization, in which

Table 12.3 Global mobility in the Big Four accounting firms

\begin{tabular}{llcc}
\hline & & \multicolumn{2}{c}{ New global assignments } \\
\cline { 2 - 4 } Firm & Program & 1630 & 1426 \\
\hline Pricewaterhouse & Global Mobility Program & $(945)$ & $(713)$ \\
Coopers & Long-term assignments & $(658)$ & $(713)$ \\
& Short-term assignments & 3800 & $2500+$ \\
Deloitte & International Mobility Program & 2150 & Fiscal Year 2009 \\
KPMG & Global Opportunities Program & N.A. & N.A. \\
Ernst \& Young & Global Exchange Program & & \\
\hline
\end{tabular}

Source: Firm websites

Note. NA = Not known 
Table 12.4 Dimensions of transfer policies in transnational professional service firms

\begin{tabular}{|c|c|c|c|}
\hline \multirow[b]{2}{*}{ Dimensions } & \multicolumn{3}{|l|}{ Reasons for transfer } \\
\hline & Fill positions & Develop managers & Develop organization \\
\hline Relative numbers & Many & Many & Many \\
\hline $\begin{array}{l}\text { Specialities } \\
\text { transferred }\end{array}$ & Fee-earning & Fee-earning & Fee-earning \\
\hline Location of host & All countries & All countries & All countries \\
\hline Direction of flow & $\begin{array}{l}\text { Between subsidiaries } \\
\text { and between } \\
\text { headquarters and } \\
\text { subsidiaries }\end{array}$ & $\begin{array}{l}\text { Between subsidiaries } \\
\text { and between } \\
\text { headquarters and } \\
\text { subsidiaries }\end{array}$ & $\begin{array}{l}\text { Between subsidiaries } \\
\text { and between } \\
\text { headquarters and } \\
\text { subsidiaries }\end{array}$ \\
\hline Age of assignee & Throughout career & Young to middle & Throughout career \\
\hline Frequency & Many moves & Several moves & Many moves \\
\hline $\begin{array}{l}\text { Nationality of } \\
\text { assignee }\end{array}$ & All nationalities & All nationalities & All nationalities \\
\hline $\begin{array}{l}\text { Personnel } \\
\text { information } \\
\text { system }\end{array}$ & $\begin{array}{l}\text { Extensive lists of } \\
\text { candidates monitored } \\
\text { by personnel in all } \\
\text { offices }\end{array}$ & $\begin{array}{l}\text { Extensive lists of } \\
\text { candidates monitored } \\
\text { by personnel in all } \\
\text { offices }\end{array}$ & $\begin{array}{l}\text { Extensive lists of } \\
\text { candidates monitored by } \\
\text { personnel in all offices }\end{array}$ \\
\hline $\begin{array}{l}\text { Power of } \\
\text { personnel } \\
\text { department }\end{array}$ & Strong & Strong & Strong \\
\hline $\begin{array}{l}\text { Strategic } \\
\text { placement and } \\
\text { distribution }\end{array}$ & Extensive & Extensive & Extensive \\
\hline
\end{tabular}

Adapted from Edstrom and Galbraith (1977, p. 253).

knowledge is shared among all subsidiaries and units of the organization. Beaverstock's (2004, 2007a, 2007b) recent analyses of expatriation within global accounting, legal, and investment banks reworked Edström and Galbraith's (1977) initial dimensions of international assignee transfer policies within organizations specifically to theorize the use of international assignments in professional services to fill positions, develop managers, and evolve the organization (Table 12.4).

\section{Global Talent in London's Financial District}

London's financial district, composed of the City of London and, since the late 1980s, Canary Wharf, has been a magnet for expatriates in banking, finance, and professional services since the end of the twentieth century following the influx of U.S., European, and Japanese banks (Michie, 2000). At the onset of the decade of the 2010s, London is the premier global financial center, ahead of New York, Singapore, and Hong Kong (Z/Yen, 2012). London's competiveness rests on its ability to attract major U.S., European, and Asian global financial institutions; the 
quality of its financial environment and regulation; and, importantly, its ability to attract and retain an international, talented labor force in fierce competition with other leading financial centers (Beaverstock, 2010; Cook et al., 2007; Jones, 2010; $\mathrm{Z} /$ Yen, 2012). London has a truly deep international talent pool of elite foreign workers of all nationalities from the European Economic Area (EEA) and non-EEA countries (City of London, 2011; Wigley, 2008).

The nature and function of occupations in London's financial district are very knowledge intensive and essentially cannot be supplanted by information technology or mass recruitment from the local, regional, or national labor market. As research has shown elsewhere (Beaverstock, 1994, 2007b; Jones, 2010; Thrift, 1994), these jobs are highly prized and require a specific set of explicit and tacit knowledge bases, which often require experience working in other financial centers or directly with global clients in secondment arrangements. The cornerstone of these high-value banking and financial services jobs is the ability to work in situ, with a leading process for knowledge exchange and transfer remaining face-to-face contact (Amin \& Thrift, 1992; Thrift, 1994). Consequently, a significant driver of the competitiveness and complementariness of London as a global financial center is the continual supply of elite, expatriate labor that comes to work in its burgeoning global banks, financial institutions, and professional services firms. Many of those workers coming into London from outside of the EEA enter as inter-company transfers (ICTs) for specific time periods to fill vacancies, for training, to develop their professional and management skills in formal programs, and to enhance the global culture of the firm (Beaverstock \& Hall, 2012).

Prior to 2009, the United Kingdom Border Agency released data on work permits for non-EEA nationals. Between 2000 and 2008, a total of 58,911 work permits were issued to non-EEA nationals in financial services (Salt, 2010). Given the structure of the United Kingdom's economy, a very large proportion of them would have entered as ICTs to work and reside in London. The London Borough of the Corporation of London (its constituency boundary is the City of London) estimated that in 2009 approximately a quarter $(75,000)$ of the City's 300,000 banking, financial, and professional services workers were foreign (Aldrick, 2009), in other words, expatriates from both EEA and non-EEA destinations. Using the Corporation of London's $25 \%$ ratio of foreign workers to total employment in City jobs, Beaverstock and Hall (2012) calculated possible numbers of expatriates in London's financial district (The City of London and Canary Wharf) in any given year since the early 2000s (Table 12.5). Thus, in 2007, at the height of the boom, there may have been as many as 104,000 foreign workers (expatriates) employed in the City of London and Canary Wharf. But these approximations could be too low because they may fail to acknowledge those hypermobile workers typical of the City's international labor market (characterized by, e.g., longer-term business travel, short-term rotations of less than 1 year, and business commuting, Faulconbridge et al., 2009). 
Table 12.5 Estimation of foreign workers in city-related jobs in the City of London and Canary Wharf, 2000-2011

\begin{tabular}{lcc}
\hline Year & City related jobs $^{\mathrm{a}}$ & ${\text { Estimated foreign workers }\left(25 \%^{\mathrm{b}} \text { of city-related jobs }\right)}^{2000}$ \\
2001 & 345,000 & 86,250 \\
2002 & 350,000 & 87,500 \\
2003 & 332,000 & 83,000 \\
2004 & 344,000 & 86,000 \\
2005 & 370,000 & 92,500 \\
2006 & 379,000 & 94,750 \\
2007 & 401,000 & 100,250 \\
2008 & 417,000 & 104,250 \\
2009 & 401,000 & 100,250 \\
2010 & 338,000 & 84,500 \\
2011 & $315,000^{c}$ & 78,750 \\
\hline
\end{tabular}

${ }^{a}$ Estimate of City-type jobs, including banking, financial intermediation, insurance and pension funds, legal, accountancy, and business consultancy (Centre for Economics and Business Research [CEBR], 2011; The Corporation of London City Stat Shots [various], and City Research Focus [various])

${ }^{\mathrm{b}}$ The Corporation of London estimated that $25 \%$ of the 300,000 City-jobs in 2009 were filled by foreign workers (Aldrick, 2009)

'Estimate by City of London of City-jobs only (i.e., excluding Canary Wharf) (CEBR, 2011)

\section{Conclusions}

In this chapter, I have argued that expatriation, also more commonly known as international assignments, remains a key strategy for a firm to transfer and exchange knowledge between subsidiaries and clients alike, irrespective of rapid improvements in ICT and travel. TNCs that engage in international production through foreign direct investment, whether in mineral extraction, manufacturing plant, or office networks, explicitly use expatriation and other modes of corporate mobilities as an organizational strategy to deepen, broaden, and enlarge intrinsic and generic knowledge within the firm. But gone are the days of one way flows of knowledge and people between the headquarters and subservient, knowledge-poor subsidiaries. As Bartlett and Ghoshal (1998) and others (e.g., Morgan, 2001), have quite rightfully acknowledged, contemporary firms are highly transnational in scope, with knowledge being shared among all subsidiaries and people flowing in multiple directions for learning, knowledge transfer and exchange, and the sharing of best practice, whether in management systems or for the rolling out of corporate policy and strategy. In the knowledge-intensive sectors of the economy, which encompass banking, finance, accounting, and legal services, as well as other activities such as advertising, the arts, and even elite sports, expatriation and corporate mobilities are a key modus operandi of the TNC, because idiosyncratic knowledge, skills, expertise, and competences are embodied in the individual worker, a function that can seldom be 
accomplished by ICT or other forms of technological transmission. As an organizational strategy, expatriation still facilitates the colocation, or immediate proximity of the knowledge-rich employee, of whatever nationality, to the specific client or work colleague to deliver, transfer, or exchange knowledge, which is often in tacit form and sticky. As the study of global accounting firms has shown, international assignments remain a major strategy by which a firm can engage with its clientele and build the knowledge capacity of its worldwide labor force, which is increasingly labeled global talent. Moreover, expatriation and other forms of corporate mobility have become a vital component of firms' global talent management and global staffing regimes.

Secondly, it is important to acknowledge that world cities are the nodes in society where knowledge is created, co-produced, and circulated within and between firms in similar sectors and agglomeration economies, or clusters. Many leading theorists acknowledge that world cities have economic agency through their command and control functions and global reach (Sassen, 2001b, 2006), with such agency being orchestrated through the strategic operations and everyday decisionmaking of boardroom executives, fee-earning professionals, and expert scientific labor. Importantly, the composition of this highly skilled labor market is global in scope, composed of both home country nationals and expatriates, who are at the forefront of knowledge production, transfer, and exchange. Indeed, as I have suggested, the world city's incumbent knowledge economy is continually being nourished by the labor processes of very highly qualified and experienced individuals of all nationalities who bring a degree of depth to the city's global talent pool. World cities are the places where global talent pools are created, sustained, and, for the very successful cities, such as London, New York, Hong Kong, and Singapore, nurtured and developed. Without such internationally focused and spatialized labor markets being reproduced through expatriation and corporate mobilities, the spatial mobility of both tacit and codified knowledge would circulate very inefficiently between firms and cities, because they are simply just not "being (there)" (Gertler, 2003).

As to the future, the management and capture of global talent is going to be highly competitive for both firms and cities. At the organizational level, corporate mobilities will consist of an array of global talent systems, from expatriation to the hypermobilities of flexipatriation with its business travel and commuting. Firms' human resource policies will respond more to clients demands for more globally flexible professionals and talented labor to deliver tailor-made solutions and expertise. With respect to world cities, competition to "win the war for talent" (Beaverstock $\&$ Hall, 2012) will become rife as cities try to outbid each other with metrics such as high rankings in quality of life indices, remuneration, and sustainability to secure talent to create economic growth and stimulus through highly efficient production and consumption systems. 


\section{References}

Accountancy Age. (2011). Top 35 International networks, associations and alliances for 2011. http://www.accountancyage.com/aa/analysis/1776670/top-accounting-networksassociations-2009

Aldrick, P. (2009, December 20). Foreign bankers threaten to quit UK in row over bonuses. The Telegraph, http://www.telegraph.co.uk/finance/newsbysector/banksandfinance/6853080/ Foreign-bankers-threaten-to-quit-UK-in-row-over-bonuses.html

Amin, A., \& Thrift, N. (1992). Neo-Marshallian nodes in global networks. International Journal of Urban and Regional Research, 16, 571-587. doi:10.1111/j.1468-2427.1992.tb00197.x

Bartlett, C. A., \& Ghoshal, S. (1998). Managing across borders: The transnational solution (2nd ed.). London: Random House.

Beaverstock, J. V. (1994). Re-thinking skilled international labour migration: World cities and banking organisations. Geoforum, 25, 323-338. doi:10.1016/0016-7185(94)90034-5

Beaverstock, J. V. (2004). 'Managing across borders': Knowledge management and expatriation in professional service legal firms. Journal of Economic Geography, 4, 157-179. doi:10.1093/ jeg/4.2.157

Beaverstock, J. V. (2005). Transnational elites in the city: British highly-skilled inter-company transferees in New York City's financial district. Journal of Ethnic and Migration Studies, 31, 245-268. doi:10.1080/1369183042000339918

Beaverstock, J. V. (2007a). Transnational work: Global professional labour markets in professional service accounting firms. In J. Bryson \& P. Daniels (Eds.), The handbook of service industries (pp. 409-431). Cheltenham: Edward Elgar.

Beaverstock, J. V. (2007b). World city networks 'from below': International mobility and inter-city relations in the global investment banking industry. In P. J. Taylor, B. Derudder, P. Saey, \& F. Witlox (Eds.), Cities in globalization: Practices, policies and theories (pp. 52-71). London: Routledge.

Beaverstock, J. V. (2010). Immigration and the UK labour market in financial services: A commentary. In M. Ruhs \& B. Anderson (Eds.), Who needs migrant workers? Labour shortages, immigration, and public policy (pp. 290-294). Oxford, UK: Oxford University Press.

Beaverstock, J. V. (2011). Serving British expatriate 'talent' in Singapore: Exploring ordinary transnationalism and the role of the 'expatriate" club.' Journal of Ethnic and Migration Studies, 37, 709-728. doi:10.1080/1369183X.2011.559714

Beaverstock, J. V., \& Boardwell, J. T. (2000). Negotiating globalization, transnational corporations and global city financial centres in transient migration studies. Applied Geography, 20, 277 304. doi:10.1016/S0143-6228(00)00009-6

Beaverstock, J. V., \& Hall, S. (2012). Competing for talent: Global mobility, immigration and the City of London's labour market. Cambridge Journal of Regions, Economy \& Society, 5, 271-288. doi:10.1093/cjres/rss005

Black, J. S., Gregersen, H. B., Mendenhall, M. E., \& Stroh, L. K. (1999). Globalizing people through international assignments. Reading: Addison-Wesley.

Brewster, C. (1991). The management of expatriates. London: Kogan Page.

Brewster, C., \& Scullion, H. (1997). A review and agenda for expatriate HRM. Human Resource Management Journal, 7, 32-41. doi:10.1111/j.1748-8583.1997.tb00424.x

Castells, M. (1996). The rise of the network society: The information age: Economy, society, and culture, Vol. 1. Oxford:Blackwell.

CEBR (2011) Despite fall in bonuses in 2010/11, growth in City workers' pay packets continues to outpace the rest of the UK. News release. 26th April 2011

Cohen, R. (1981). The new international division of labour, multinational corporations and urban hierarchy. In M. Dear \& A. J.Scott (Eds.), Urbanization and urban planning in capitalist society (pp. 287-319). London: Methuen. 
Collings, D. G., McDonnell, A., Gunnigle, P., \& Lavelle, J. (2010). Swimming against the tide: Outwards staffing flows from multinational subsidiaries. Human Resource Management, 49, 575-598. doi:10.1002/hrm.20374

Collings, D. G., \& Scullion, H. (2006). Strategic motivations for international transfers: Why do MNCs use expatriates? In H. Scullion \& D. G. Collings (Eds.), Global staffing (pp. 39-56). London: Routledge.

Cook, G. A. S., Pandit, N. R., Beaverstock, J. V., Taylor, P. J., \& Pain, K. (2007). The role of location in knowledge creation and diffusion: Evidence of centripetal and centrifugal forces in the City of London financial services agglomeration. Environment and Planning A, 39, 1325 1345. doi:10.1068/a37380

City of London (2011). Access to global talent: The impact of migration limits on UK financial and professional business services. Retrieved from http://nfib.police.uk/NR/rdonlyres/58175A36F7BD-4DD2-8DF8-9D3E95B0D894/0/BC_RS_AccesstoGlobalTalent_FINAL.pdf

Corporation of London (various). City Stat Shots. London: The Corporation of London.

Corporation of London (various). City Research Focus. London: The Corporation of London.

Deloitte (2010). Deloitte 2010 annual review: Reaching new heights, as one. Retrieved from http:// annualreport.deloitte.co.uk/2010/

Deloitte (2012). The global talent challenge: Getting new people in new jobs in new places. Retrieved from http://www.deloitte.com/view/en_GB/uk/services/consulting/human-capital/7 0297716ac1b4310VgnVCM1000001a56f00aRCRD.htm

Dicken, P. (2011). Global Shift: Mapping the changing contours of the world economy (6th ed.). London: Sage. (Original work published 1986)

Dunning, J. H. (1993). The globalization of business: The challenge of the 1990s. London: Routledge.

Edström, A., \& Galbraith, J. (1977). Transfer of managers as a coordination and control strategy in multinational corporations. Administrative Science Quarterly, 22, 248-263.

Evans, P., Pucik, P., \& Barsoux, J. L. (2002). The global challenge: Frameworks for international human resource management. New York: McGraw-Hill.

Ewers, M. C. (2007). Migrants, markets and multinationals: Competition among world cities for the highly skilled. GeoJournal, 68, 119-130. doi:10.1007/s10708-007-9077-9

Faulconbridge, J. (2008). Managing the transnational law firm: A relational analysis of professional systems, embedded actors and time-space sensitive governance. Economic Geography, 84, 185-210. doi:10.2139/ssrn.1155053

Faulconbridge, J. R., Beaverstock, J. V., Derudder, B., \& Witlox F. (2009). Corporate ecologies of business travel in professional service firms: Working towards a research agenda. European Urban and Regional Studies, 16, 295-308. doi:10.1177/0969776409104694

Faulconbridge, J. R., Beaverstock, J. V., Taylor, P. J., \& Nativel, C. (2011). The globalization of advertising: Agencies, cities and spaces of creativity. London: Routledge.

Favell, A. (2008). Eurostars and Eurocities: Free movement and mobility in an integrating Europe. Malden, MA: Blackwell.

Fechter, A. M., \& Walsh, K. (Eds.). (2012). The new expatriates. Post-colonial approaches to mobile professionals. London: Routledge

Florida, R. L. (2002). The rise of the creative class. New York: Basic Books.

Friedmann, J. (1986). The world city hypothesis. Development and Change, 17, 69-83.

Friedmann, J., \& Wolff, G. (1982). World city formation: An agenda for research and action. International Journal of Urban and Regional Research, 6, 309-344. doi:10.1111/j.1468-2427.1982.tb00384.x

Gertler, M. S. (2003). Tacit knowledge and the economic geography of context, or the undefinable tacitness of being (there). Journal of Economic Geography, 3, 75-99. doi:10.1093/jeg/3.1.75

Greenwood, R., \& Lachman, R. (1996). Change as an underlying theme in professional service organizations: An introduction. Organization Studies, 17, 563-572. doi:10.1177/017084069601700401 
Greenwood, R., Rose, T., Brown, J. L., Cooper, D. J., \& Hinings, B. (1999). The global management of professional services: The example of accounting. In S. R. Clegg, E. Ibarra-Colado \& L. Bueno-Rodriquez (Eds.), Global management: Universal theories and local realities (pp. 265-269). London: Sage.

Hall, S. (2009). Financialised elites and the changing nature of finance capitalism: Investment bankers in London's financial district. Competition and Change, 13, 173-189.

Hanlon, G. (1994). The commercialisation of accountancy_Flexible accumulation and the transformation of the service class. London: Palgrave MacMillan.

Hanlon, G. (1999). International professional labour markets and the narratives of accountants. Critical Perspectives on Accounting, 10, 199-221. doi:10.1006/cpac.1997.0212

Harvey, W. S. (2008). Strong or weak ties: British and Indian expatriate scientists finding jobs in Boston. Global Networks, 8, 453-473.

Hymer, S. (1972). The multinational corporation and the law of uneven development. In N. Jagdish \& J. Bhagwati (Eds.), Economics and the world order from the 1970s to the 1990s (pp. 113140). New York: Collier-Macmillian.

Jones, A. (2008). The rise of global work. Transactions of the Institute of British Geographers, 33, 12-26. doi:10.1111/j.1475-5661.2007.00284.x

Jones, A. (2010). Immigration and the UK labour market in financial services: A case of conflicting policy challenges? In M. Ruhs \& B. Anderson (Eds.), Who needs migrant workers? Labour shortages, immigration, and public policy (pp. 259-289). Oxford: Oxford University Press. doi:10.1093/acprof:oso/9780199580590.003.0009

Kolossov, V., Vendina, O., \& O'Loughlin, J. (2002). Moscow as an emergent world city: International links, business developments, and entrepreneurial city. Eurasian Geography and Economics, 43, 170-196. doi:10.2747/1538-7216.43.3.170

Lai, K. P. Y. (2009). Global cities in competition? A qualitative analysis of Shanghai, Beijing and Hong Kong as financial centres. GaWC Research Bulletin 313. Retrieved from www.lboro. ac.uk/gawc/rb/rb313.html.

Lowendahl, B. R. (1997). Strategic management of professional service firms. Copenhagen: Copenhagen Business School Press.

Lowendahl, B., Revang, O., \& Fosstenlokken, S. N. (2001). Knowledge and value creation in professional service firms: A framework for analysis. Human Relations, 54, 911-931. doi: $10.1177 / 0018726701547006$

Mahroum, S. (2000). Highly skilled globetrotters: Mapping the international migration of human capital. R\&D Management, 30, 23-32. doi:10.1111/1467-9310.00154

Mastercard Worldwide (2008). Worldwide centers of commerce index. Retrieved from http:// www.mastercard.com/us/company/en/insights/pdfs/2008/MCWW_WCoC-Report_2008.pdf

Mellahi, K., Frynas, J. G., \& Finlay, P. (2005). Global strategic management. New York: Oxford University Press.

Mercer Group (2011). 2011 quality of living worldwide city rankings-Mercer survey. Retrieved from http://allianceau.com/pics/advant/2011_Mercer.pdf

Meusburger, P., Funke, J., \& Wunder, E. (Eds.). (2009). Milieus of creativity. An interdisciplinary approach to spatiality of creativity. Knowledge and Space: Vol. 2. Dordrecht: Springer.

Meyer, D. R. (2000). Hong Kong as a global metropolis. Cambridge, UK: Cambridge University Press.

Michie, R. C. (Ed.) (2000). The development of London as a financial centre: Volume 1: 17001850. London: Tauris.

Millar, J., \& Salt, J. (2009). Portfolios of mobility: The movement of expertise in transnational corporations in two sectors-aerospace and extractive industries. Global Networks, 8, 25-50. doi:10.1111/j.1471-0374.2008.00184.x

Ministry of Manpower (2009). Data extracted from the Annual Employment Change by Industry. Retrieved from http://stats.mom.gov.sg/Pages/ExploreStatisticsPublications.aspx\#Publication Search?topic=employment 
Morgan, G. (2001). Transnational communities and business systems. Global Networks, 1, 113 130. doi:10.1111/1471-0374.00008

Morris, T., \& Empson, L. (1998). Organisation and expertise: An exploration of knowledge bases and the management of accounting and consulting firms. Accounting, Organizations and Society, 23, 609-624. doi:10.1016/S0361-3682(98)00032-4

Nachum, L. (1999). The origins of the international competitiveness of firms: The impact of location and ownership in professional service industries. Cheltenham: Edward Elgar.

Nohria, N., \& Ghoshal, S. (1997). The differentiated network: Organizing multinational corporations for value creation. San Francisco: Jossey-Bass.

Organisation for Economic Co-operation and Development (2003). Service providers on the move: Labour mobility and the WTO General Agreement on Trade in Services. Policy Brief Paper, August 2003. Retrieved from http://www.oecd.org/trade/services-trade/8890089.pdf

Olds, K. (2007). Global assemblage: Singapore, foreign universities, and the construction of a "global education hub". World Development, 35, 959-975. doi:10.1016/j. worlddev.2006.05.014

Patel, S. (2007). Mumbai: The mega-city of a poor country. In K. Segbers (Ed.), The making of global city regions (pp. 64-84). Baltimore: John Hopkins University Press.

PricewaterhouseCoopers (2000a). Managing a virtual world: Key trends 2000/2001. London: PricewaterhouseCoopers.

PricewaterhouseCoopers (2000b). International Assignments, European Policy and Practice: Key Trends 1999-2000. London: PricewaterhouseCoopers.

PricewaterhouseCoopers (2010a). Talent mobility 2020: The next generation of international assignments. Retrieved from http://www.pwc.com/gx/en/managing-tomorrows-people/futureof-work/pdf/talent-mobility-2020.pdf

PricewaterhouseCoopers (2010b). Building relationships, creating value: Global annual review 2010. Retrieved from https://www.pwc.com/ec/es/publicaciones/assets/pdf/global-annualreview-2010.pdf

Salt, J. (2010). International migration and the United Kingdom: Report to SOPEMI (available from the author, Migration Research Unit, University College, London).

Sassen, S. (2001a). Cracked castings: Notes towards an analytics for studying transnational processes. In L. Pries (Ed.), New transnational social spaces (pp. 187-207). London: Routledge.

Sassen, S. (2001b). The Global City. Princeton, Princeton University Press.

Sassen, S. (2006). Cities in a world economy (4th ed.). Thousand Oaks: Pine Forge Press.

Saxenian, A. (2007). The new Argonauts: Regional advantage in a global economy. Cambridge, MA: Harvard University Press.

Schuler, R. S., Jackson, S. E., \& Tarique, I. (2011). Global talent management and global talent challenges: Strategic opportunities for IRHM. Journal of World Business, 46, 506-516. doi:10.1016/j.jwb.2010.10.011

Scullion, H., \& Collings, D. G. (Eds.). (2006). Global staffing. London: Routledge.

Scullion, H., Collings, D. G., \& Caligiuri, P. (2010). Global talent management. Journal of World Business, 45, 105-108.

Shortland, S. (2009). Gender diversity in expatriation. Evaluating theoretical perspectives. Gender in Management: An International Journal, 24, 365-386. http://dx.doi. org/10.1108/17542410910968814

Smith, M. P. (1999). Transnationalism and the city. In R. A. Beauregard \& S. Body-Gendrot (Eds.), The urban movement: Cosmopolitan essays on the late 20th century city (pp. 119-139). Thousand Oaks: Sage.

Smith, M. P., \& Favell, A. (Eds.). (2006). The human face of global mobility. New Brunswick: Transactions

Sparrow, P., Brewster, C., \& Harris, H. (2004). Globalizing human resource management. London: Routledge.

Tarique, I., \& Schuler, R. S. (2009). Global talent management: Literature review, integrative framework, and suggestions for further research. Journal of World Business, 45, 122-133. 
theCityUK (2012). Accounting. Retrieved from http://www.thecityuk.com/research/our-work/ reports-list/

Thrift, N. J. (1994). On the social and cultural determinants of international financial centres: The case of the City of London. In S. Corbridge, R. L. M. \& N. J. Thrift (Eds.), Money, power and space (pp. 327-355). Oxford: Blackwell.

Tung, R. L. (1988). The new expatriates: Managing human resources abroad. Cambridge, MA: Ballinger.

Whelan, E., Collings, D. G., \& Donnelian, B. (2010). Managing talent in knowledge-intensive settings. Journal of Knowledge Management, 14, 488-504.

Wigley, R. (2008). London: Winning in a changing world: Review of the competitiveness of London's financial centre. London: Merril Lynch Europe.

Z/Yen (2012). The Global Financial Centres Index 11. Retrieved from http://www.zyen.com/PDF/ GFCI\%2011.pdf

Open Access This chapter is distributed under the terms of the Creative Commons Attribution 4.0 International License (http://creativecommons.org/licenses/by/4.0/), which permits use, duplication, adaptation, distribution and reproduction in any medium or format, as long as you give appropriate credit to the original author(s) and the source, provide a link to the Creative Commons license and indicate if changes were made.

The images or other third party material in this chapter are included in the work's Creative Commons license, unless indicated otherwise in the credit line; if such material is not included in the work's Creative Commons license and the respective action is not permitted by statutory regulation, users will need to obtain permission from the license holder to duplicate, adapt or reproduce the material. 